\title{
Optimal Location of Biogas Complexes in the Region
}

\author{
D. G. Nefedov ${ }^{1}$, E. V. Kasatkina ${ }^{2}$ \\ Dept. of Mathematical Support for Information Systems, Kalashnikov Izhevsk State Technical University, \\ Izhevsk, Russian Federation \\ E-mail: ${ }^{1}$ denisnefedov1@yandex.ru, ${ }^{2}$ e.v.trushkova@gmail.com
}

Received: November 14, 2017

\begin{abstract}
The report provides the application of biogas technologies at livestock enterprises as a complex solution of alternative energy supply of heat sources on natural gas. The organization of biogas complexes is a high-cost event and requires the selection of the optimal location variant, which consists in minimizing the total costs associated with the production of biogas and its delivery to consumers. Optimization is based on the construction of mathematical models for the location of elements of a distributed production structure. The method of solving this problem is based on the use of a genetic algorithm with real coding and the use of parallel computations. In this paper, an example of the solving the problem of the optimal location of biogas complexes in the territory of the Udmurt Republic of Russian Federation is presented. The estimation of the economic effect of substitution of natural gas with biogas is given, the optimal volume of its production is determined taking into account the solution of the ecological problem of processing livestock wastes and the possibility of selling by-products from biogas production. The results of the calculations are presented in graphical and tabular form.
\end{abstract}

Keywords: biogas complex, facility location, intermediate production, final product, genetic algorithm.

\section{INTRODUCTION}

The distributed industrial structure is typical for many branches of industry and agriculture associated with the production and recycling of various types of raw materials and minerals [1]. This industry also includes the production of biogas from animal wastes $[2,3]$. The construction of mathematical models and tools for calculating the optimal production structure and facility location for processing raw materials into products allows the most rational use of available resources and, accordingly, to achieve the best values of the placement performance index, which consists in minimizing costs or maximizing profits [4].

Problems of mathematical modeling of facility location at the modern level are devoted to the works of M. Daskin, Z. Drezner, S. Hakimi, R. Churche and others [5]. They describe various location models taking into account the multilevel and multiproduct nature of production, time and probabilistic parameters, restrictions on the output. Methods for solving the problems of facility location are described in M. Fisher, R. Galvao, S. Revile, B. Bockaya, J. Zhang, E. Erkut, J. Bramell, E. Rolland, K. Rosing [6, 7].

The meaningful formulation of the problem of allocating elements of a distributed production structure is as follows (see Figure 1).

(C) D. G. Nefedov, E. V. Kasatkina, 2017 
Raw materials storage points

$$
(i=\overline{1, I})
$$

Livestock farms

Intermediate product production points

$$
(j=\overline{1, J} ; m=\overline{1, M})
$$

Biogas complexes (biogas)

Final product production points $(k=\overline{1, K})$

Heat sources (heat energy)

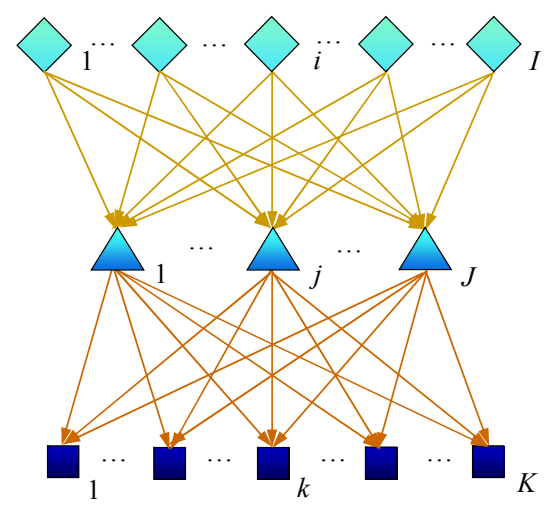

Figure 1. Scheme of interrelation of raw materials storage points, intermediate product production points and final product production points

There are a number of $K$ production points for the final product. To produce it, $M$ interchangeable types of intermediate products are used. For its production, raw materials are used, prepared in raw material storage points, the total number of which is equal to $I$. It is required to find the volumes of output of intermediate products in each of $J$ potential points of its production. Possible positions of intermediate products manufactured points are determined in advance, and they may or may not coincide with the location of the storage points of raw materials and points of the final product production [8].

\section{MATHEMATICAL MODEL}

The mathematical model of considered problem is based on the methodology for calculating the cost of intermediate production and the final product, given in $[9,10]$.

The objective function of the problem is to minimize the total costs for the final product, taking into account the costs of production and delivery of intermediate products:

$$
\begin{gathered}
C=C^{I P}+C^{F P} \rightarrow \min , \\
C^{I P}=\sum_{j=1}^{J} \sum_{m=1}^{M} F_{j}^{m}\left(V_{j}^{m}\right)+\sum_{i=1}^{I} \sum_{j=1}^{J} \sum_{k=1}^{K} \sum_{m=1}^{M} \tau^{m}\left(\alpha^{m} g_{i j}^{m}+g_{j k}^{m}\right) x_{i j k}^{m} D_{k}, \\
C^{F P}=\sum_{k=1}^{K} \sum_{m=1}^{M} E_{k}^{m}\left(D_{k}^{m}\right),
\end{gathered}
$$

where $C$ are total costs for production of intermediate and final products, rub./year; $C^{I P}$ are costs for transportation of raw materials, production of intermediate products and its delivery to the final product production points, rub./year; $C^{F P}$ are costs for processing intermediate products into the final product at production points, rub./year; $V_{j}^{m}$ is the output of $m$-th type of intermediate products at the $j$-th production point, un.i.p./year; $D_{k}$ is the output of the final product at the $k$-th production point, un.f.p./year; $D_{k}^{m}$ is the output of the final product at the $k$-th production point on the $m$-th type of intermediate products, un.f.p./year; $F_{j}^{m}\left(V_{j}^{m}\right)$ are costs of processing raw materials into the $m$-th type of intermediate products at the $j$-th production point, rub./year; $E_{k}^{m}\left(D_{k}^{m}\right)$ are costs for processing $m$-th type of intermediate produc- 
tion into the final product at the $k$-th production point, rub./year; $g_{i j}^{m}$ are costs of transporting a unit of raw materials used to produce the $m$-th type of intermediate production, between the $i$-th raw materials storage point and $j$-th point of its production, rub./un.r.m.; $g_{j k}^{m}$ are costs of transporting a unit of $m$-th type of intermediate production between the $j$-th point of its production and the $k$-th point of final product production, rub./un.i.p.; $x_{i j k}^{m}$ are managed variables that determine a share of the final product from the $k$-th point of its production, produced in the $m$-th type of intermediate production from the $j$-th point of its production with the consumption of the raw materials from the $i$-th storage point.

The costs of processing of raw materials into the intermediate production $F_{j}^{m}\left(V_{j}^{m}\right)$ are determined on the basis of technical and economic calculation:

$$
F_{j}^{m}\left(V_{j}^{m}\right)=a_{j}^{m} V_{j}^{m}+b_{j}^{m} \Theta\left(V_{j}^{m}\right), j=\overline{1, J}, m=\overline{1, M},
$$

where $a_{j}^{m}$ are the conditional-constant costs per unit of the $m$-th type of intermediate production output at the $j$-th point of its production, rub./un.i.p.; $b_{j}^{m}$ are the conditional-constant costs for the entire output of the $m$-th type of intermediate production at the $j$-th point of its production, rub./year; $\Theta(\chi)$ is Heaviside function.

The costs of processing of intermediate production into the final product are

$$
E_{k}^{m}\left(D_{k}^{m}\right)=\tilde{a}_{k}^{m} D_{k}^{m}+\tilde{b}_{k}^{m} \Theta\left(D_{k}^{m}\right), k=\overline{1, K}, m=\overline{1, M},
$$

where $\tilde{a}_{k}^{m}$ are the conditional-constant costs per unit of the final product at the $k$-th point of its production on the $m$-th type of intermediate production, rub./un.f.p.; $\tilde{b}_{k}^{m}$ are the conditionalconstant costs for the entire output of the final product at the $k$-th point of its production on the $m$-th type of intermediate production, rub./year.

The following relationships are accepted as the restrictions:

$$
\begin{gathered}
V_{j}^{m}=\tau^{m} \sum_{i=1}^{I} \sum_{k=1}^{K} x_{i j k}^{m} D_{k}, j=\overline{1, J}, m=\overline{1, M} ; \\
D_{k}^{m}=D_{k} \sum_{i=1}^{I} \sum_{j=1}^{J} x_{i j k}^{m}, k=\overline{1, K}, m=\overline{1, M} ; \\
\alpha^{m} \tau^{m} \sum_{j=1}^{J} \sum_{k=1}^{K} x_{i j k}^{m} D_{k} \leq W_{i}^{m}, i=\overline{1, I}, m=\overline{1, M} ; \\
\sum_{i=1}^{I} \sum_{j=1}^{J} \sum_{m=1}^{M} x_{i j k}^{m}=1, k=\overline{1, K} ; \\
x_{i j k}^{m} \in[0 ; 1], i=\overline{1, I}, j=\overline{1, J}, k=\overline{1, K}, m=\overline{1, M} .
\end{gathered}
$$

where $W_{i}^{m}$ is the volume of raw materials at the $i$-th point of accumulation, used to produce the $m$-th type of intermediate production, un.r.m./year.

Relations (6), (7) establish a balance between the output of intermediate production at its production points and demand for it at the final product production points. Expression (8) determines the balance between the required volume of raw materials and the potential of the raw materials base at the points of its accumulation. The constraint (9) reflects the condition 
for the satisfaction all the final product production point with the intermediate production. The restriction (10) shows the domain of the desired solution.

\section{Numerical Solution AlgORITHM}

The presented mathematical model belongs to the class of problems of nonlinear optimization [11]. In this case, the search for the optimal solution is complicated by the large dimension of the vector of the desired solutions. The specificity of the problem (1)-(10) is the inability to differentiate the objective function. Therefore, the main problem is the choice of the method for the numerical solution of the optimization problem.

The method for solving this problem is based on a genetic algorithm with real coding. A block diagram of this algorithm using parallel computations is presented in Figure 2.

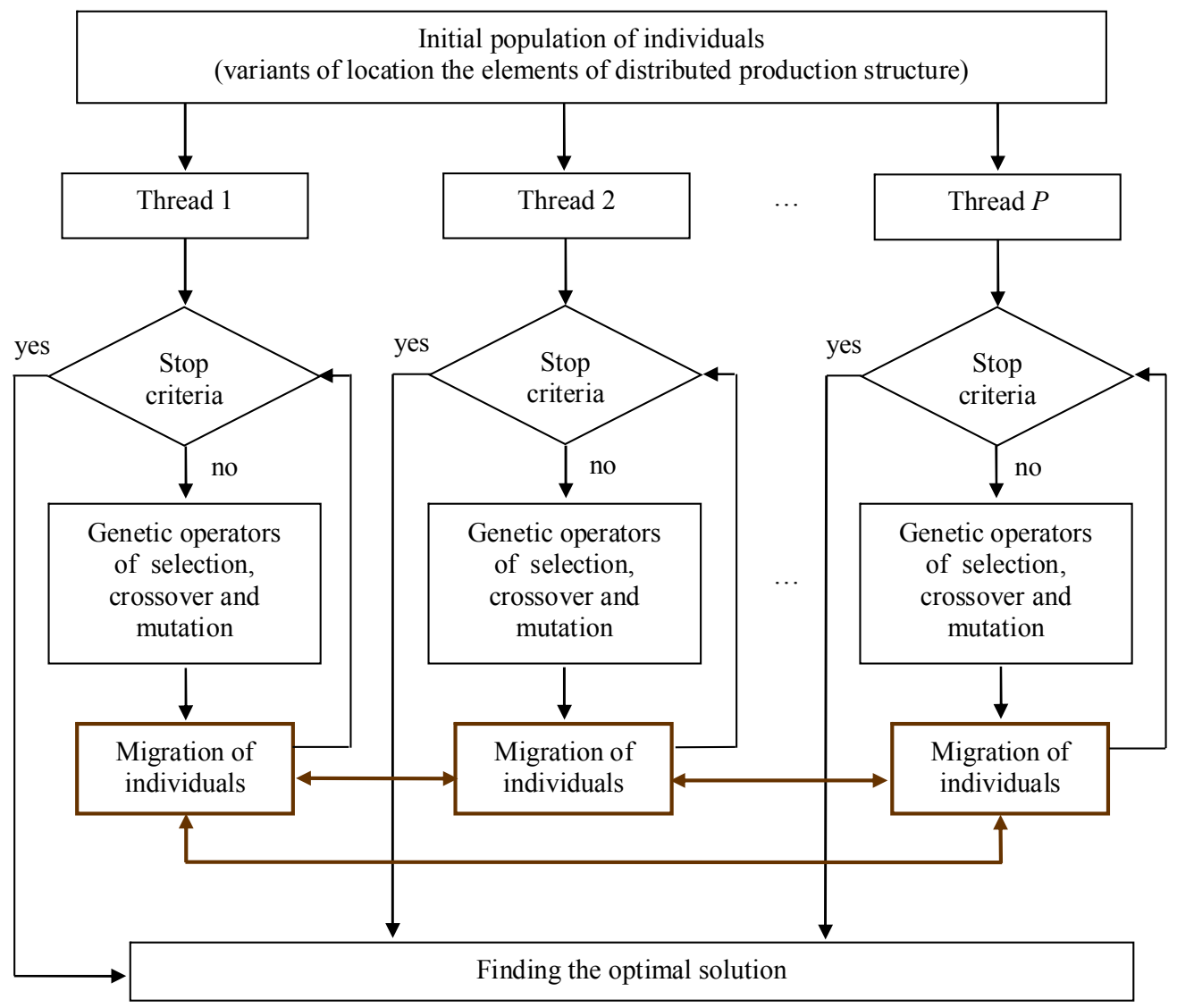

Figure 2. Block diagram of genetic algorithm using parallel computations

Search for solution of the problem involves several stages:

1. Formation of the initial population of individuals.

2. Assessment of fitness of individuals.

3. Application of genetic operators. Over individuals within each flow, the action of genetic operators is carried out: selection, crossover and mutation.

4. Migration of individuals. At this stage, there is a movement of individuals from one thread to another - migration is carried out.

5. Finding the optimal solution of the problem. The best individual of a given thread is compared to the best individuals of the remaining threads, and the winner becomes the solution of the problem. 
The partitioning of the population into several threads and the execution of intra-thread operations by individual processors of the computing device leads to a significant increase in the overall speed of searching for the optimal solution.

\section{OPTIMAL LOCATION SCHEME FOR THE BIOGAS COMPLEXES ON THE TERRITORY OF UDMURT REPUBLIC}

In Udmurt Republic in 2015 , more than $50 \%$ of the animal wastes were provided by the 60 livestock farms $[12,13]$. They are chosen as potential locations for biogas complexes. 383 heat sources have been chosen as potential biogas consumption points [14]. The organization of biogas complexes is a high-cost event, and the cost of biogas and heat energy on biogas is reduced due to large volume of production that can be achieved by using the raw materials from large livestock enterprises. Further increase in production is achieved at the expense of smaller enterprises. This leads to a parametric problem of determining the largest economically feasible volume of biogas production, in which the total cost of heat energy on biogas, including the cost of its production, does not exceed the cost of heat energy on natural gas, including the cost of its purchase. To solve the problem, the above mathematical model is used, in which the optimization criterion is minimization of the cost of heat energy on biogas subject to a given volume of production. Figure 3 shows the optimal values of objective function $C$ - the cost of heat energy - for each of the given volumes of biogas production $V^{b g}$. In the same figure, for comparison, an analogous dependence is given for the cost of heat energy on natural gas. The increase in biogas production due to smaller livestock enterprises leads to an outpacing increase in the cost of biogas as compared to the fixed cost of natural gas, which also affects the cost of heat energy.

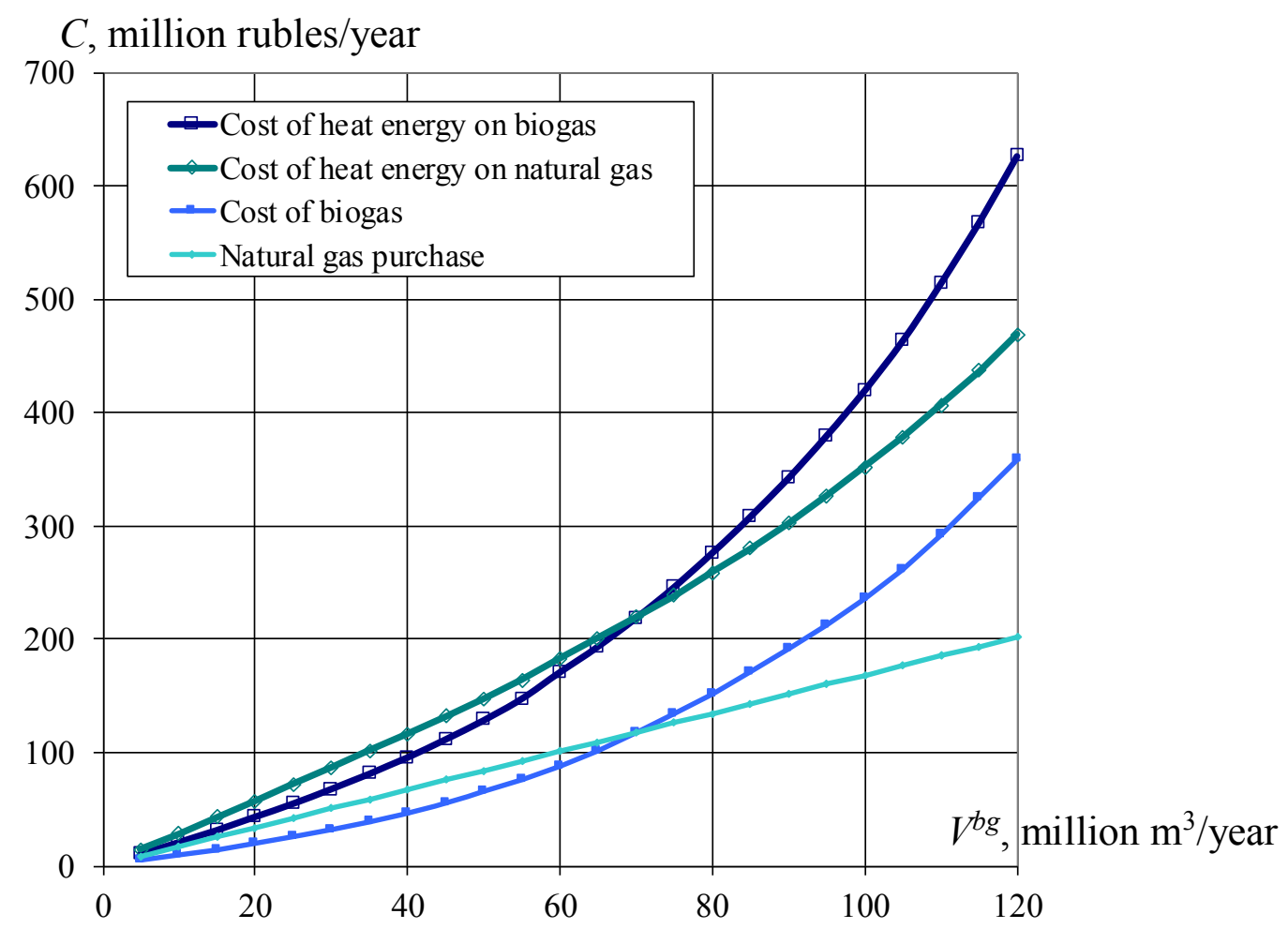

Figure 3. Dependence of the cost of heat energy production on biogas and natural gas from total biogas production 
The presented results show that with $V^{b g}>70$ million $\mathrm{m}^{3} /$ year the use of biogas to replace them natural gas under the conditions of the Udmurt Republic is economically unprofitable. The optimal scheme of facility location corresponding to the volume of 70 million $\mathrm{m}^{3}$ of biogas per year includes 16 biogas complexes located near the largest livestock enterprises supplying 62 heat sources (see Figure 4).

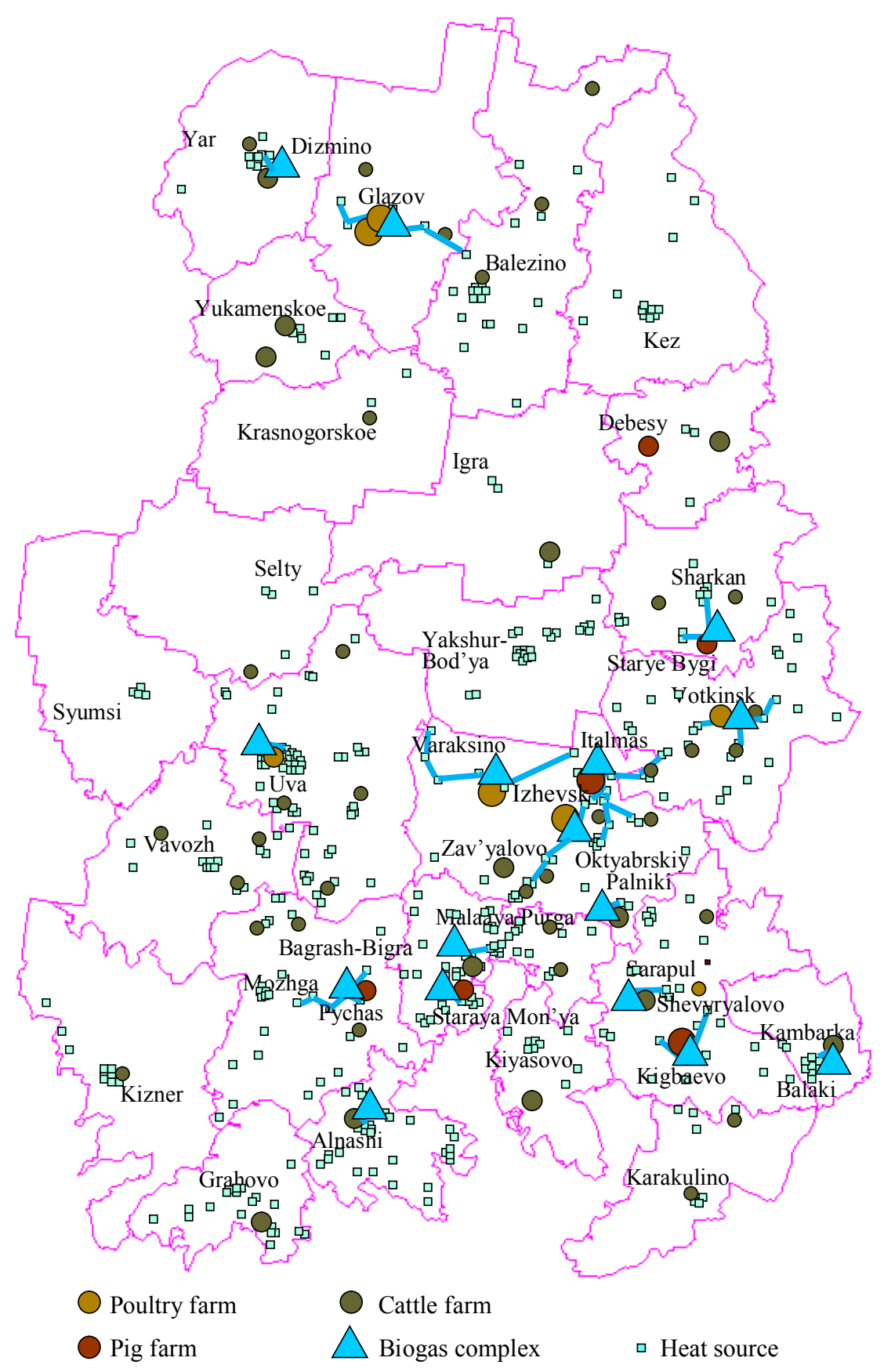

Figure 4. Optimal location of biogas complexes

Volumes of biogas production on biogas complexes are given in Table 1. As calculations have shown, in this case the total costs for the production of heat energy including fuel costs will be 215 million rubles per year. The average cost of production of heat energy on biogas for selected heat sources will be equal to 701 rubles / Gcal. 
Table 1. Biogas complexes in Udmurt Republic

\begin{tabular}{cccc}
\hline No & $\begin{array}{c}\text { Location } \\
\text { of biogas complex }\end{array}$ & $\begin{array}{c}\text { Volume of biogas production, } \\
\text { million } \mathbf{~ m}^{\mathbf{3}} / \text { year }\end{array}$ & $\begin{array}{c}\text { Number of heat sources } \\
\text { supplied }\end{array}$ \\
\hline 1 & Italmas & 21.53 & 12 \\
2 & Varaksino & 11.20 & 6 \\
3 & Glazov & 8.21 & 5 \\
4 & Oktyabrskiy & 5.77 & 4 \\
5 & Kigbaevo & 5.07 & 3 \\
6 & Votkinsk & 2.66 & 5 \\
7 & Pychas & 2.65 & 5 \\
8 & Dizmino & 2.29 & 3 \\
9 & Alnashi & 2.08 & 2 \\
10 & Uva & 1.82 & 3 \\
11 & Balaki & 1.67 & 2 \\
12 & Bagrash-Bigra & 1.38 & 2 \\
13 & Palniki & 1.17 & 1 \\
14 & Shevyryalovo & 0.97 & 3 \\
15 & Starye Bygi & 0.85 & 3 \\
16 & Staraya Mon'ya & 0.73 & 3 \\
\hline \multicolumn{7}{r}{} & Total & $\mathbf{7 0 . 0 5}$ & $\mathbf{6 2}$ \\
\hline
\end{tabular}

Figure 5 shows the dependence of the annual economic effect $E$ obtained by the substitution of natural gas with biogas on heat sources, on the volume of biogas production. Its value is determined by the difference between the total costs for the heat energy production on natural gas and biogas.

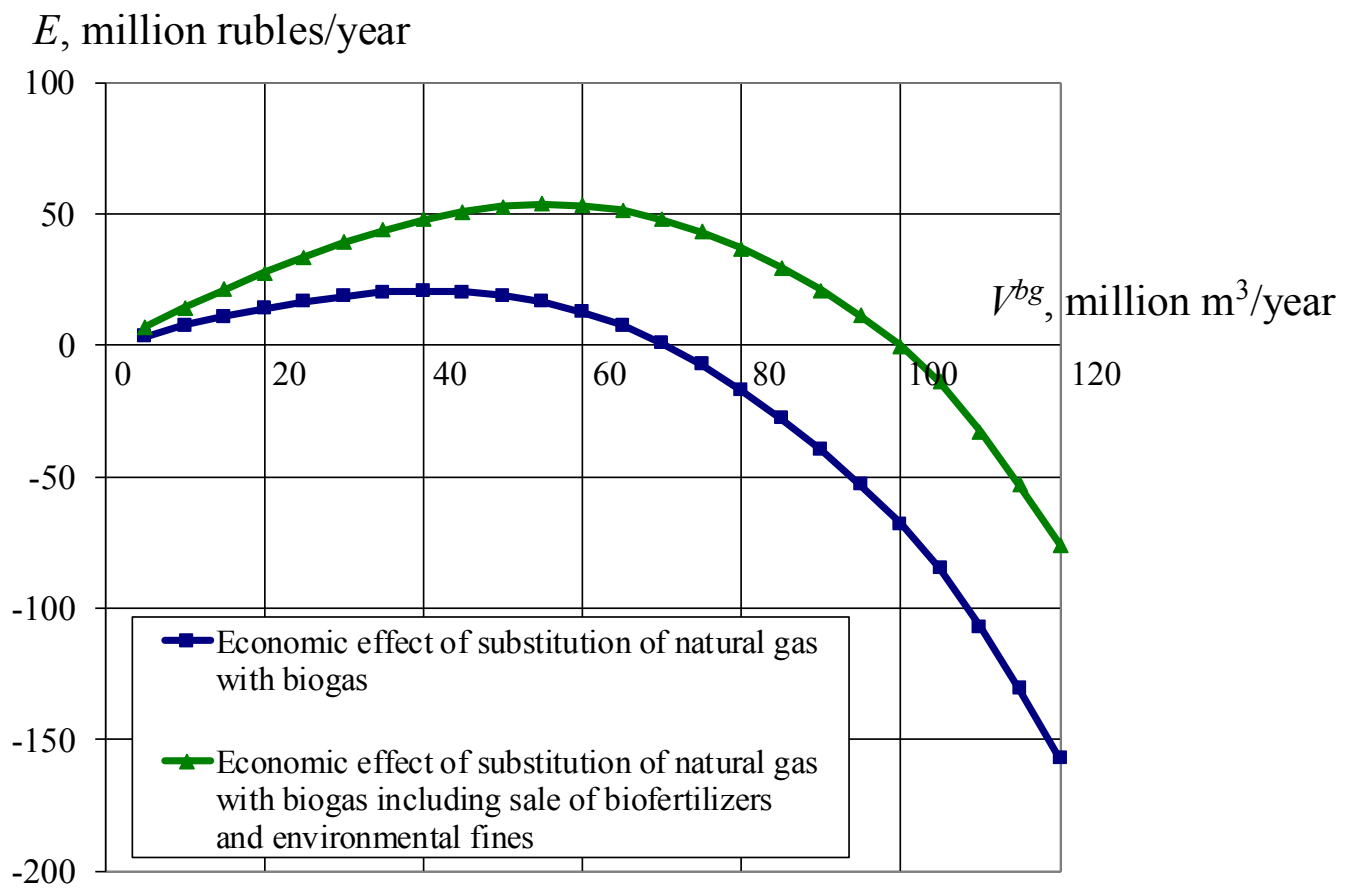

Figure 5. Dependence of the annual effect on substitution of natural gas with biogas of the total volume of its production 
The biogas production yields the ecologically clean organic fertilizers. In addition, the waste of livestock enterprises, according to the classification of the Ministry of Natural Resources and Ecology of the Russian Federation, is a hazard class III substance, the utilization of which in the production of biogas allows the elimination of environmental fines. Taking into account the income from the sale of solid biofertilizers at a cost of 500 rubles per ton and exclusion of environmental fines equal to 100 rubles per ton of dry matter, economically profitable biogas production in Udmurt Republic increases from 70 to 100 million $\mathrm{m}^{3}$ per year, and the maximum economic effect increases from 20 to 55 million rubles per year.

\section{CONCLUSION}

As a result of solving the problem of optimizing the location of biogas complexes in the territory of the Udmurt Republic it is determined that the maximum amount of biogas production, at which it is economically feasible to replace natural gas, is 70 million $\mathrm{m}^{3}$ per year. For this volume, the optimal number and location of biogas complexes supplying 62 heat sources is given. Taking into account the income from the sale of biofertilizers and the exclusion of environmental fines, economically profitable output of biogas increases to 100 million $\mathrm{m}^{3}$ per year.

\section{REFERENCES}

1. Rusyak, I. G., Ketova, K. V, \& Trushkova, E. V. (2011). Logistic task of fuel supply for the regional distributed heat supply system. Journal of Knowledge Management, Economics and Information Technology, 1(7), 445-477. - Retrieved from: http://www.scientificpapers.org/wp-content/files/1235_Ekaterina_Trushkova_ Logistic_Task_of_Fuel_Supply_for_the_Regional_Distributed_Heat_Supply_System.pdf.

2. Budiyono, I. N., \& Widiasa, S. J. (2010). Increasing biogas production rate from cattle manure using rumen fluid as inoculums. International Journal of Basic \& Applied Sciences IJBAS-IJENS, 10(1), 68-74. doi:10.12777/ijse.6.1.31-3.

3. Balussou, D., Heffels, T., McKenna, R., Möst, D., \& Fichtner, W. (2014). An evaluation of optimal biogas plant configurations in Germany. Waste and Biomass Valorization, 5(5), 743-758. doi:10.1007/s12649-0139284-1.

4. Daskin, M. S. (2008). What you should know about location modeling. Naval Research Logistics, Economics and Information Technology, 55(4), 283-294. doi:10.1002/nav.20284.

5. Daskin, M. S. (2011). Network and discrete location: models, algorithms, and applications. New York, USA: Wiley. doi:10.1002/9781118032343.

6. Bozkaya, B., Zhang, J., \& Erkut, E. (2002). An efficient genetic algorithm for the p-median problem. In Z. Drezner, H. W. Hamacher (Eds.), Facility location: applications and theory (pp. 179-205). Berlin, Germany: Springer.

7. Price, K., Storn, R., \& Lampinen, J. (2005). Differential evolution: a practical approach to global optimization. Berlin, Germany: Springer.

8. Rusyak, I. G., \& Nefedov, D. G. (2012). Reshenie zadachi optimizacii shemy razmeshcheniya proizvodstva drevesnyh vidov topliva po kriteriyu sebestoimosti teplovoj energii [Solution of optimization problem of wood fuel facility location by the thermal energy cost criterion]. Komp'yuternyye issledovaniya $i$ modelirovaniye [Computer Research and Modeling], 4(3), 651-659 (in Russian).

9. Rusyak, I. G., Ketova, K. V., \& Nefedov, D. G. (2017). Matematicheskaya model' i metod resheniya zadachi optimal'nogo razmeshcheniya proizvodstva drevesnyh vidov topliva [Mathematical model and method for solving problem of optimal location of wood fuels facility]. Izvestiya Rossiyskoy Akademii Nauk. Energetika [Proceedings of the Russian Academy of Sciences. Power Engineering], 2017(2), 177-187 (in Russian). 
10. Rusyak, I. G., Presnukhin, V. K., Ketova, K. V., Korolev, S. A., \& Trushkova, E. V. (2010). Razrabotka koncepcii toplivoobespecheniya raspredelennoj regional'noj sistemy teplosnabzheniya mestnymi vozobnovlyaemymi vidami topliva [Development of the concept of fuel supply distributed regional heating system of local renewable fuels]. Energobezopasnost' $i$ Energosberezhenie [Energy Safety and Energy Economy], 2010(5), 14-20 (in Russian).

11. Ruszczyński, A. (2006). Nonlinear optimization. Princeton, NJ, USA: Princeton University Press.

12. Korolev, S. A., Valiullin, M. A., Merzlyakov, A. Yu., \& Sairanov, A. S. (2013). Analiz potenciala vozobnovlyaemyh istochnikov energii Udmurtskoj Respubliki [Analysis of the renewable energy potential of the Udmurt Republic]. Intellektual'nye Sistemy v Proizvodstve [Intelligent Systems in Manufacturing], 2013(2), 194-198 (in Russian).

13. Korolev, S. A., \& Maykov, D. V. (2011). Vliyanie klimaticheskih uslovij na teplovoj rezhim raboty biogazovoj ustanovki [Influence of climatic conditions on the thermal mode of a biogas plant]. Bulletin of Kalashnikov ISTU, 2011(2), 209-213 (in Russian).

14. Korolev, S. A., \& Maykov, D. V. (2013). Informacionno-analiticheskaya sistema proektirovaniya structury, rascheta i optimizacii tehnologicheskih i economicheskih parametrov biogazovyh kompleksov [Informationanalytical system of structure design, calculation and optimization of technological and economic parameters of biogas complexes]. Intellektual'nye Sistemy v Proizvodstve [Intelligent Systems in Manufacturing], 2013(2), 198-202 (in Russian). 